\title{
Selective Cytotoxicity Evaluation in Anticancer Drug Screening of Boehmeria virgata (Forst) Guill Leaves to Several Human Cell Lines: HeLa, WiDr, T47D and Vero
}

\author{
Wardihan ${ }^{1}$, Muhammad Rusdi' ${ }^{2}$, Gemini Alam ${ }^{3}$, Lukman $^{4}$ \\ and Marianti A. Manggau ${ }^{4}$ \\ ${ }^{1}$ Faculty of Medicine, Hasanuddin University 90245, East Sulawesi Makassar, Indonesia \\ ${ }^{2}$ Faculty of Mathematics and Natural Sciences, Islamic University of Makassar 90245, Makassar, Indonesia \\ ${ }^{3}$ Department of Pharmacognosy and Phytochemistry, Faculty of Pharmacy, Hasanuddin University 90245 \\ Makassar, Indonesia \\ ${ }^{4}$ Department of Biopharmacy, Faculty of Pharmacy, Hasanuddin University 90245, East Sulawesi Makassar \\ Indonesia 90245, Makassar, Indonesia
}

\begin{abstract}
Cancer is one of the leading causes of death worldwide. Many researchers have attempted to develop new treatments that will improve the prognosis of cancer patients. Indonesian forests, one of the most important world's biodiversity, but little is known about chemical and/or pharmacological potential of these plants. The aim of this study to investigate selective cytotoxicity of $B$. virgata against of various cancer cell lines. The ethanolic extract of $B$. virgata leaves can act against HeLa, Widr, T47D and Vero cell lines with IC $_{50} 18.991 \pm 0.234,18.925 \pm 1.277$, $12.732 \pm 0.945$ and $16.022 \pm 0.663 \mu \mathrm{g} / \mathrm{ml}$ with selective index $0.844,0.847,1.258$ and 1.000 , respectively. We highlight the significant cytotoxic effect of $B$. virgata from the leaves, which introduces promising expectations for new projects in chemistry, pharmacology and toxicology although non selective in these cell lines.
\end{abstract}

Key words: B. virgata, selective cytotoxicity, MTT, HeLa, Widr, T47D and Vero.

\section{INTRODUCTION}

Cancer is a leading cause of disease worldwide and was estimated that 12.7 million new cancer cases occurred worldwide. ${ }^{1}$ An estimated 12.66 million people were diagnosed with cancer was estimated to account for around $14 \%$ of all deaths (due to any cause) worldwide. ${ }^{2}$

Plants play an important role as a source of effective anticancer agents. Currently, over $60 \%$ of used anticancer agents are derived in one way or another from natural sources, including plants, marine animals and microorganisms. ${ }^{3}$ There are worldwide efforts to discover new anticancer agents from plants.

Correspondence to: Lukman

Tel +62 8971561010,

Email: lukman_m01@yahoo.co.id
Many of the drugs, which we use today are based on folk remedies and subsequent ethnopharmacological studies and the traditional medicines are generally more acceptable from a cultural and spiritual perspective. ${ }^{4}$ The $B$. virgata leaf have been widely used in Traditional Makassar Medicine to treat cancer. ${ }^{5}$ B. virgata is classified in the family Urticaceae. ${ }^{6}$ The genus Boehmeria have been widely studied by several author, in search of answers to their cytotoxic effect ${ }^{7}$ but no B. virgata was reported yet.

In this investigation, cytotoxic effects, $\mathrm{IC}_{50}$ and selectivity of ethanolic extract of $B$. virgata leaves on cancer (HeLa, WiDr and T47D) and normal (Vero) cell lines were studied, using the MTT reduction test. 


\section{MATERIAL AND METHODS}

Plant material. Leaves of $B$. virgate were collected from Malino (South Sulawesi, Makassar, Indonesia) in the month of March, the plant was indentified and authenticated. Fresh plant leaves were shade dried at room temperature and ground into a fine powder.

Extraction. Five hundred gram of plant materials was used for extraction using ethanol by maceration method. The extraction time was fixed for $24 \mathrm{~h}$. The extract was concentrated by rotary evaporator and dried through lyophilization. ${ }^{8}$

Cell cultures. We used 3 cell lines: HeLa as servix cell line, WiDr as a colon adenocarcinoma, T47D as human ductal breast epithelial tumor cell line and Vero as normal cell line. HeLa and T47D were cultured in RPMI 1650, WiDr was cultured in Dulbecco's Modified Eagle Medium (DMEM). Vero was cultured in M199 medium. All cells were subcultured after mild trypsinization with typsinEDTA (Sigma-Aldrich, USA), trypan blue dye (Sigma-Aldrich, USA) exclusion assay was performed to determine the cell number and viability. All media (Sigma-Aldrich, USA) were supplemented at $10 \%$ with fetal bovine serum (Gibco) and streptomycin plus penicillin (100 ug/ml and 100 $\mathrm{u} / \mathrm{ml}$, respectively; Sigma-Aldrich, USA). The cell line were kept at $37^{\circ} \mathrm{C}, 98 \%$ relative humidity with $5 \% \mathrm{CO}_{2}$ atmosphere.

Cytotoxic assay. This assay was carried out for $24 \mathrm{~h}$ to evaluate the cytotoxicity effect. ${ }^{9}$ Sufficient number of exponentially growing cells to avoid confluence of the culture during treatments were seeded at 10.000 cells $/ \mathrm{mL}$ to evaluate possible cytotoxic effect in Iwaki 96-well plates. The treatment started $24 \mathrm{~h}$ after seeding (to improve environment adaptation), after $24 \mathrm{~h}$ of treatment, the medium was replaced and cultures were maintained for another $24 \mathrm{~h}$ before the cell viability quantification. Control was always treated with the same amount of DMSO as used in the corresponding experiments.

Cell viablity: MTT test. The tetrazolium salt MTT was used as an indicator of mammalian cell survival and proliferation. ${ }^{10}$ Yellow 3-(4,5dimethylthiazol-2-yl)-2,5-diphenyl tetrazolium bromide (MTT) method consists in the absorption of yellow tetrazolim salts by mitochondrial reductases of metabolically active cells, called formazan. Formazan accumulated in intacellular cell, is extracted by adding an organic solvet. ${ }^{11}$ Solubilised formazan reagent is measured by Elisa microplate reader at 595 $\mathrm{nm}^{12}$ The culture in 96-well plates were incubated with $100 \mu \mathrm{l}$ of fresh supplemented medium and 100 $\mu \mathrm{L}$ of MTT $(5 \mathrm{mg} / \mathrm{ml})$. The MTT formazan that produced by the cultured cell was added $100 \mu \mathrm{l}$ of DMSO to each well to solubilize the MTT formazan. After incubate for $24 \mathrm{~h}$ at room temperature, the plate were read with an Elisa Reader at $595 \mathrm{~nm}$ (bio-Rad). Percentage inhibition was calculated as follows:

Percentage inhibition $(\%)=$

$$
\frac{\text { OD of control-OD of treatment }}{\text { OD of control }} \times 100
$$

Data analysis: All the experiment were performed in triplicate at least. Dose response curves were plotted and the $\mathrm{IC}_{50}$ values (concentrations at which cellular effects are inhibited by $50 \%$ ) were calculated using linear regression analysis compared with untreated cells.

\section{RESULTS AND DISCUSSION}

Cytotoxic effect of ethanol extract from $B$. virgate leaves was tested against $\mathrm{HeLa}$ using colorimetric method MTT assay. All the cells were exposed to various concentration: 1.95 ; $3.91 ; 7.81$; 15.63; 31.25; 62.50 and $125.00 \mu \mathrm{g} / \mathrm{ml}$ (Figure 1).

Cytotoxic effect of ethanol extract from $B$. virgate leaves was tested against WiDr using colorimetric method MTT assay. All the cells were exposed to various concentration: $1.95 ; 3.91 ; 7.81$; 15.63; 31.25; 62.50 and $125.00 \mu \mathrm{g} / \mathrm{m}$. (Figure 2).

Cytotoxic effect of ethanol extract from $B$. virgate leaves was tested against T47D using colorimetric method MTT assay. All the cells were exposed to various concentration: 1.95 ; $3.91 ; 7.81$; 15.63; 31.25; 62.50 and $125.00 \mu \mathrm{g} / \mathrm{ml}$ (Figure 3). 


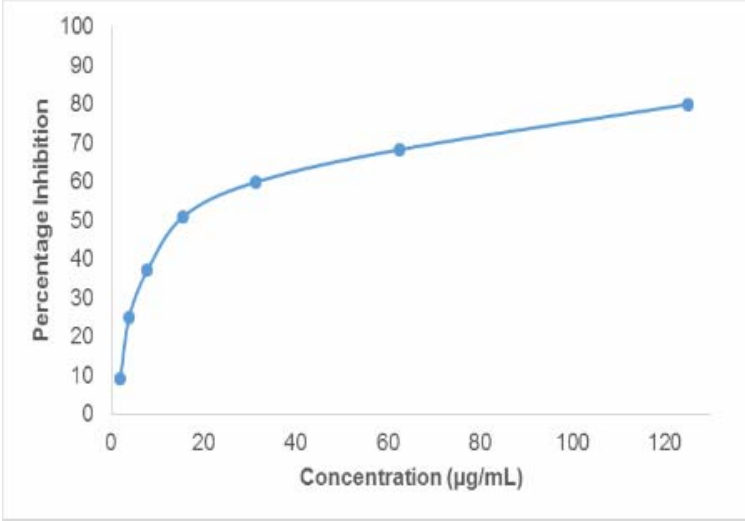

Figure 1. Cytotoxicity of ethanolic extracts of $B$. virgate leaves on the growth of HeLa cells were examined my MTT assay. Dose response curves constructed in the range $1.95-125.00$ $\mu \mathrm{g} / \mathrm{ml}$ after $24 \mathrm{~h}$.

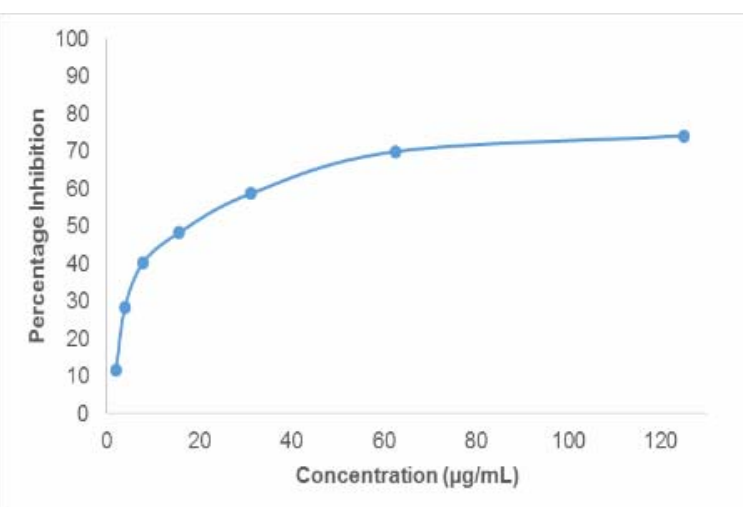

Figure 2. Cytotoxicity of ethanolic extracts of $B$. virgate leaves on the growth of WiDr cells were examined my MTT assay. Dose response curves constructed in the range 1.95 - 125.00 $\mu \mathrm{g} / \mathrm{ml}$ after $24 \mathrm{~h}$.

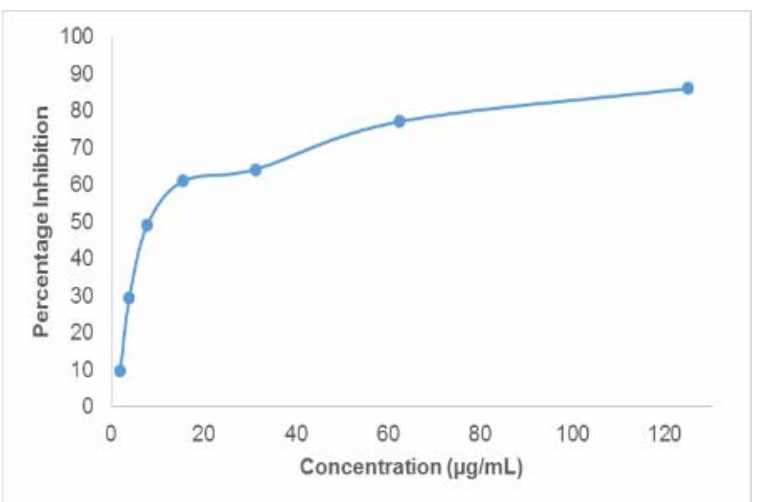

Figure 3. Cytotoxicity of ethanolic extracts of $B$. virgate leaves on the growth of T47D cells were examined my MTT assay. Dose response curves constructed in the range 1.95 - 125.00 $\mu \mathrm{g} / \mathrm{ml}$ after $24 \mathrm{~h}$.
Cytotoxic effect of ethanol extract from $B$. virgate leaves was tested against Vero using colorimetric method MTT assay. All the cells were exposed to various concentration: $1.95 ; 3.91 ; 7.81$; 15.63; 31.25; 62.50 and $125.00 \mu \mathrm{g} / \mathrm{ml}$ (Figure 4).

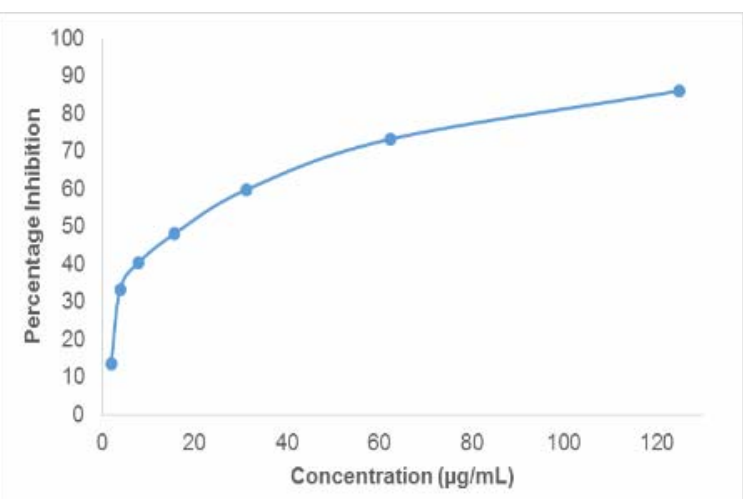

Figure 4. Cytotoxicity of ethanolic extracts of $B$. virgate leaves on the growth of Vero cells were examined my MTT assay. Dose response curves constructed in the range 1.95 - 125.00 $\mu \mathrm{g} / \mathrm{ml}$ after $24 \mathrm{~h}$.

The $\mathrm{IC}_{50}$ was determined based on concentration that induced 50\% inhibition on the growth of the treated cells as compared to the untreated cells in triplicate after $24 \mathrm{~h}$ treated.

Table 1. IC $_{50}$ and selectivity of ethanolic extract of $B$. virgata on various cell lines.

\begin{tabular}{lcc}
\hline $\begin{array}{l}\text { Cancer } \\
\text { cell line }\end{array}$ & $\mathrm{IC}_{50}(\mathrm{ppm})$ & Selectivity Index (SI) \\
\cline { 3 - 3 } & & $\begin{array}{c}\text { (IC }_{50} \text { of cancer cell line / } \\
\left.\text { IC }_{50} \text { of Vero }\right)\end{array}$ \\
\hline HeLa & $18.991 \pm 0.234$ & 0.844 \\
WiDr & $18.925 \pm 1.277$ & 0.847 \\
T47D & $12.732 \pm 0.945$ & 1.258 \\
Vero & $16.022 \pm 0.663$ & 1.000 \\
\hline
\end{tabular}

\section{DISCUSSION}

The treatment of oral cancer relies on surgery, radiotherapy, chemotherapy or a combination of these methods. ${ }^{13}$ Poor survival rates still occur, particularly for patients in advanced stages of the disease. ${ }^{14}$ Natural products display a wide range of diversity in terms of their chemical structures and pharmacological properties. Several important antitumor drugs have been isolated from plants. ${ }^{15}$ 
The B. virgata of the genus Boehmeria have been widely studied by several author, in search of answers to their cytotoxic effect but no $B$. virgata was reported for each activity.

As the SI demonstrates the differential activity of extract, the greater the SI value is, the more selective it is. An SI value less than 2 indicates general toxicity of the pure compound ${ }^{16}$. Based on this, the SI data shown in Table 1 indicate that the extract was non selective in this cancer cell line, especially in HeLa, WiDr and T47D. This suggests its general toxicity to the cell.

Boehmeriasins $\mathrm{A}$ and $\mathrm{B}$, new phenanthroquinolizidine alkaloids isolated form the aqueous ethanolic extract of Boehmeria genus, have cytotoxic activity against 12 cell lines. ${ }^{17}$ Boehmeriasin A inhibits the proliferation of breast cancer cell MDA-MB-231 via the G1 phase cell cycle arrest and differentiation induction.

\section{CONCLUSIONS}

In conclusion, we highlight the significant cytotoxic effect of $B$. virgata from the leaves, which introduces promising expectations for new projects in chemistry, pharmacology and toxicology although it was found to be non selective in HeLa, Widr and T47D cell lines. These results may aid in achieving the development of an anticancer medicine obtained from the rain forest.

\section{REFERENCES}

1. Ferlay, J., Shin, H.R., Bray, F., Forman, D., Mathers, C. and Parkin, D.M. 2010a. GLOBOCAN 2008 v1. 2, Cancer Incidence and Mortality Worldwide: IARC CancerBase No. 10 [Internet].

2. Ferlay, J., Shin, H.R., Bray, F., Forman, D., Mathers, C. and Parkin D.M. 2010b. Estimates of worldwide burden of cancer in 2008: GLOBOCAN 2008. Intl. J. Cancer. 127, 289328291

3. Newman, D.J., Cragg, G.M. and Snader, K.M. 2003. Natural products as sources of new drugs over the period 1981-2002. J. Nat. Prod. 66, 1022-1037.

4. Ramawat, K.G. and Goyal, S. 2008. The Indian herbal drugs scenario in global perspectives, In Ramawat KG, Merillon JE
"Bioactive Molecules and Medicinal Plants, Springer, Berlin Heidelberg, New York, 323.

5. Manggau, M., Hasan, H., Wahyudin, E. and Haryono, K. 2011. Efek Farmakologi Tanaman Antikanker yang Digunakan oleh Masyarakat Sulawesi Selatan. In: Mufidah and Lukman. Balitbangda Sulawesi Selatan, 2011, ISBN 978 6028400558 .

6. Brands, S.J. 2007. Systema Naturae 2000 The taxonomicon. Universal Taxonomic Services, The Netherland. Cox, P.A. 1994. Ciba Foundation Symposium, Chichester, John Wiley \& Sons. pp. 25-44.

7. Yan, J., Luo, D., Luo, Y., Gao, X., and Zhang, G. 2006. Induction of G1 arrest and differentiation in MDA-MB-231 breast cancer cell by boehmeriasin A, a novel compound from plant. Intl. J. Gynecol Cancer. 16, 165-170.

8. Manggau, M., Mufidah and Lindequist, U. 2009. Antiproliferation Against Human Bladder Cancer 5637 Cell Line and Antioxidant Activity of Various Plant Extracts, The Indonesian J. Nat. Prod. 6, 247-250

9. Mesia, G.K., Tona, G.L., Nanga, T.H., Cimanga, R.K., Apers, S., Cos, P., Maes, L., Pieters, L., and Vlietinck, A.J. 2008. Antiprotozoal and cytotoxic screening of 45 plant extracts from Democratic Republic of Congo, $J$. Ethnopharmacol. 115(3), 409-415

10. Marshall, N.J., Goodwin, C.J. and Holt, S.J. 1995. A critical assessment of the use of microculture tetrazolium assays to measure cell growth and function. Growth Regul 5, 69-84.

11. van Meerloo, J., Kaspers, G.J. and Cloos, J. 2011. Cell sensitivity assays: the MTT assay, Methods Mol. Biol. 731, 237-245.

12. Shah, G.V., Muralidharan, A., Thomas, S., Gokulgandhi, M., Mudit, M., Khanfar, M. and El Sayed, K. 2009. Identification of a small molecule class to enhance cell-cell adhesion and attenuate prostate tumor growth and metastasis, Mol. Cancer Ther. 8, 509-520.

13. Hsu, S., Singh, B., Schuster, G. 2004. Induction of apoptosis in oral cancer cells: agents and mechanisms for potential therapy and prevention. Oral Oncol. 40, 461-473

14. Yao, M., Epstein, J.B., Modi, B.J., Pytynia, K.B., Mundt, A.J. and Feldman, L.E. 2007. Current surgical treatment of squamous cell carcinoma of the head and neck. Oral Oncol. 43, 213-223.

15. Wall, M.E. and Wani, M.C. 1995. Camptothecin and taxol: discovery to clinic-thirteenth Bruce F. Cain Memorial Award Lecture. Cancer Res. 55, 753-760.

16. Koch, A., Tamez, P., Pezzuto, J., and Soejarto D. 2005. Evaluation of plants used for antimalarial treatment by the Massai of Kenya. J. Ethnopharmacol. 101, 95-99.

17. Luo, Y., Liu, Y., Luo, D., Gao, X., Li, B. and Zhang, G. 2003. Cytotoxic alkaloids from Boehmeria siamensis, Planta Med. 69, 842-845. 
